\title{
ANALISIS TINDAK PIDANA PENGANCAMAN MELALUI PESAN SINGKAT
}

\author{
Andi Irriana D. Sulolipu \\ Mahasiswa Program Pascasarjana Universitas Muslim Indonesia Makassar \\ email : andiirriana sulolipu@yahoo.com
}

\begin{abstract}
Proof of criminal offense through short message service based on at least 2 evidences plus judge's confidence. Legal evidence can be in the form of witness statements, expert information, letters, instructions and explanations of defendants and information / electronic documents as an extension of evidence in the provisions of the ITE Law, while the print is an extension of documentary evidence in the Criminal Code. Therefore, the elements to be met, ie intentionally, without rights, transmit, the object of Electronic Information and / or electronic documents containing threats of violence or intimidating personally addressed.
\end{abstract}

Keywords : Criminal Acts; Threat; Short Message;

\section{Abstrak}

Bukti tindak pidana melalui layanan pesan singkat berdasarkan setidaknya 2 bukti ditambah keyakinan hakim. Bukti hukum dapat berupa pernyataan saksi, informasi ahli, surat, instruksi dan penjelasan terdakwa dan informasi / dokumen elektronik sebagai perpanjangan bukti dalam ketentuan UU ITE, sedangkan cetakan adalah perpanjangan dari bukti dokumenter dalam Kode kriminal. Oleh karena itu, unsur-unsur yang harus dipenuhi, yaitu sengaja, tanpa hak, mentransmisikan, objek Informasi Elektronik dan / atau dokumen elektronik yang mengandung ancaman kekerasan atau intimidasi yang ditujukan secara pribadi.

Kata kunci: Tindakan Pidana; Ancaman; Pesan Singkat;

\section{A. PENGANTAR}

Pemanfaatan Tekhnologi Informasi, media dan komunikasi telah mengubah aktivitas sosial masyarakat, baik perilaku masyarakat maupun peradaban manusia secara global. Perkembangan tekhnologi informasi dan komunikasi telah pula menyebabkan hubungan dunia tanpa batas dan menyebabkan perubahan sosial, ekonomi dan budaya secara signifikan berlangsung demikian cepat.

Kesiapan sumber daya manusia yang belum memadai dalam penggunaan tekhnologi informasi baik kesiapan dari segi kemampuan kecerdasan maupun kesiapan mental, menjadikan kecanggihan tekhnologi informasi ini sebagai sarana yang rawan digunakan sebagai media berbuat kejahatan, atau telah mempengaruhi lahirnya bentuk-bentuk perbuatan hukum baru. Salah satu bentuk kejahatan yang sifatnya baru, adalah pengancaman melalui media elektronik khususnya penggunaan handphone 
dengan mengirim Layanan Pesan Singkat. Jika dikaitkan dengan pola baru dalam kejahatan pengancaman melalui media sosial internet atau media elektronik, maka dirasakan cukup sulit menjerat pelaku dengan menggunakan pasal dalam KUHP, sehingga pemerintah kemudian mengundangkan aturan baru yang lebih spesifik mengatur tentang ketentuan perbuatan (tindak pidana) yang berkaitan dengan penggunaan media elektronik, yaitu UU ITE.

Selain permasalahan tersebut, alat bukti yang diatur dalam Kitab Undang-Undang Hukum Acara Pidana (KUHAP) tidak lagi dapat mengakomodir perkembangan teknologi informasi, terutama bentuk kejahatan baru yang sering disebut dengan cybercrime. Pembuktian merupakan faktor yang sangat penting, mengingat informasi elektronik bukan saja belum terakomodasi dalam sistem hukum acara Indonesia secara komprehensif, melainkan juga ternyata sangat rentang untuk diubah, disadap, dipalsukan dan dikirim ke berbagai penjuru dunia dalam hitungan detik.

Jika dikaitkan dengan cybercrime, maka unsur membuktikan dengan kekuatan alat bukti yang sah dalam KUHAP, merupakan masalah yang penting untuk diantisipasi baik pada unsur kesalahan dan adanya perbuatan pidana. Urgensi persoalan cybercrime, menjadi fokus masalah terutama dalam mengungkapkan pembuktian terhadap tindak pidana pengancaman yang dilakukan melalui layanan pesan singkat. Menjadi manarik untuk dibahas secara mendalam terutama pada problematik pembuktian dan unsur-unsur yang dipenuhi dalam tindak pidana pengancaman melalui layanan pesan singkat.

\section{B. ANALISIS DAN PEMBAHASAN}

\section{Pembuktian Tindak Pidana Pengancaman Melalui Layanan Pesan Singkat}

Beberapa tahun terakhir ini, perkembangan dan kemajuan tekhnologi komunikasi dan informatika demikian pesat dan hampir semua kalangan masyarakat dapat merasakan dan menikmatinya, contohnya pada perkembangan teknologi telepon seluler (handphone).

Semakin maraknya pengguna telepon seluler tidak dipungkiri pula, bahwa setiap perkembangan teknologi senantiasa membawa dampak, salah satunya adalah menyebabkan terjadinya tindak pidana seperti tindak pidana pengancaman melalui layanan pesan singkat.

Selain permasalahan diatas, alat bukti sebagaimana yang diatur dalam Kitab Undang-Undang Hukum Acara Pidana (KUHAP) tidak lagi dapat mengakomodir perkembangan tekhnologi informasi.

Untuk dapat menentukan salah atau tidaknya terdakwa menurut sistem pembuktian yang dianut oleh KUHAP, maka harus terdapat unsur-unsur sebagai berikut :

a. Kesalahan terdakwa harus terbukti sekurang-kurangnya dua alat bukti yang sah;

b. Berdasarkan dua alat bukti yang sah kemudian Mejelis Hakim memperoleh keyakinan bahwa tindak pidana benar-benar terjadi dan terdakwalah yang bersalah melakukannya. 
Sistem pembuktian ini, didasarkan pada Pasal 183 KUHAP yang menentukan bahwa:"Hakim tidak boleh menjatuhkan pidana kepada seorang kecuali apabila dengan sekurang-kurangnya dua alat bukti yang sah ia memperoleh keyakinan bahwa suatu tindak pidana benar-benar terjadi dan bahwa terdakwalah yang bersalah melakukannya."

Atas dasar Pasal 183 KUHAP tersebut, maka KUHAP menggunakan sistem pembuktian negatif. Ini berarti bahwa dalam pembuktian harus dilakukan penelitian, apakah terdapat alat bukti yang cukup sesuai dengan ketentuan undang-undang, serta ada atau tidaknya keyakinan hakim akan kesalahan terdakwa. Namun demikian, meskipun cukup bukti yang sah, tetapi jika hakim tidak yakin, atau sebaliknya hakim telah yakin tetapi tidak cukup bukti, maka hakim belum boleh menjatuhkan pidana kepada terdakwa.

Sistem pembuktian seperti ini, digunakan dalam peradilan pidana, termasuk untuk mengadili perkara tindak pidana ITE yang memuat unsur pemerasan dan pengancaman.

Undang-Undang Nomor 11 Tahun 2008 tentang Informasi dan Transaksi Elektronik, kemudian memperluas pengertian alat bukti, sehingga mampu memberikan kepastian hukum dalam penyelesaian perkara tindak pidana tekhnologi informasi di pengadilan.

Alat bukti dalam pemeriksaan perkara tindak pidana teknologi informasi diatur dalamPasal 44 UU ITE bahwa Alat bukti penyidikan, penuntutan dan pemeriksaan di sidang pengadilan menurut ketentuan undang-undang ini sebagai berikut:

a. Alat bukti sebagaimana dimaksud dalam ketentuan perundang-undangan, dan

b. Alat bukti berupa informasi elektronik dan/atau dokumen elektronik sebagaimana dimaksud dalam Pasal 1 angka 4 dan angka 5 serta Pasal 5 ayat (1), ayat (2) dan ayat (3).

Pasal 5 ayat (1) dan ayat (2) UU ITE memberikan solusi atas kekosongan hukum acara pidana pada perkaracybercrime.Dalam Pasal 5 ayat (1) UU ITE dapat dikelompokkan menjadi dua bagian. Pertama, informasi elektronik dan/atau dokumen elektronik. Kedua, hasil cetak dari informasi elektronik dan/atau dokumen elektronik.

Informasi elektronik dan dokumen elektronik tersebut akan menjadi alat bukti elektronik (digital evidence). Sedangkan hasil cetak dari informasi elektronik dan dokumen elektronik akan menjadi alat bukti surat.

Selanjutnya dalam Pasal 5 ayat (2) UU ITE mengatur bahwa informasi elektronik dan/atau dokumen elektronik dan/atau hasil cetaknya merupakan perluasan dari alat bukti hukum yang sah sesuai dengan hukum acara yang berlaku di Indonesia.

Jika dikaitkan dengan pola baru dalam tindak pidana pengancaman yang dilakukan melalui media elektronik khususnya dengan layanan pesan singkat, maka ini dirasakan cukup sulit untuk menjerat pelaku tindak pidana pengancaman melalui layanan pesan singkat menggunakan ketentuan dalam KUHP. Guna mengatur tata cara penggunaan teknologi informasi dan komunikasi, Pemerintah menerbitkan Undang-Undang Nomor 11 Tahun 2008 tentang Informasi dan Transaksi Elektronik (UU ITE).

Al-Ishlah: Vol.21 No.1 Mei 2019 


\section{Unsur-Unsur Tindak Pidana Pengancaman Melalui Layanan Pesan Singkat}

Mengenai tindak pidana pengancaman diatur dalam Pasal 335 ayat (1) angka 1 dan angka 2 KUHP, yaitu:

"1. Barangsiapa secara melawan hukum memaksa orang lain supaya melakukan, tidak melakukan atau membiarkan sesuatu, dengan memakai kekerasan, atau dengan memakai ancaman kekerasan, baik terhadap orang itu sendiri maupun orang lain;

2. Barangsiapa memaksa orang lain supaya melakukan, tidak melakukan atau membiarkan sesuatu dengan ancaman pencemaran atau pencemaran tertulis."

Mengenai tindak pidana pengancaman yang diatur dalam Pasal 335 KUHP tersebut, merupakan ketentuan pasca adanya putusan Mahkamah Konstitusi yang menghapus frasa "sesuatu perbuatan lain maupun perlakuan yang tidak menyenangkan". Ketentuan ini mengatur tentang pengancaman baik ancaman kekerasan (angka 1) maupun ancaman pencemaran atau pencemaran tertulis (angka 2).

Jika dianalisis Pasal 335 ayat (1) angka 1 tersebut, maka unsur-unsur tindak pidana adalah :

1. Pelaku adalah barangsiapa, artinya setiap orang yang melakukan perbuatan tersebut yang mampu bertanggung jawab menurut hukum.

2. Bentuk perbuatan adalah memaksa, dimana yang dimaksud dengan memaksa adalah menyuruh orang untuk melakukan sesuatu ( atau tidak melakukan sesuatu), sehingga orang tersebut melakukan sesuatu (atau tidak melakukan sesuatu) yang berlawanan dengan kehendaknya sendiri;

3. Objek adalah orang, bahwa perbuatan tesebut ditujukan kepada orang.

4. Dilakukan secara melawan hukum;

5. Cara melakukan perbuatan, yaitu dilakukan dengan kekerasan maupun ancaman kekerasan.

Selanjutnya Pasal 335 ayat (1) angka 2 KUHP, menentukan unsur- unsur tindak pidana, yaitu:

1. Barangsiapa;

2. Memaksa (melakukan atau tidak melakukan);

3. Orang (objeknya);

4. Secara melawan hukum;

5. Dengan ancaman pencemaran atau pencemaran tertulis.

Ketentuan dalam Pasal 335 ayat (1) angka 1 dan angka 2 ini, samasama merupakan bentuk pengancaman terhadap seseorang, hanya saja pada angka 1 bentuk ancamannya, ialah dengan kekerasan sedangkan dalam angka 2 bentuk ancamannya, ialah ancaman pencemaran atau pencemaran tertulis.

Berdasarkan substansi ketentuan diatas, jika dikaitkan dengan pola baru dalam tindak pidana pengancaman yang dilakukan melalui media elektronik,

Al-Ishlah: Vol.21 No.1 Mei 2019 
khususnya dengan layanan pesan singkat, maka hal ini dirasakan cukup sulit untuk menjerat pelaku tindak pidana pengancaman melalui layanan pesan singkat dengan menggunakan ketentuan dalam KUHP. Karena itu, untuk mengatur tata cara penggunaan tekhnologi informasi dan komunikasi, Pemerintah mengeluarkan Undang-Undang Nomor 11 Tahun 2008 tentang Informasi dan Transaksi Elektronik (UU ITE).

Di dalam UU ITE tersebut, diatur mengenai perbuatan yang dilarang dan diancam dengan pidana yang berkaitan dengan penggunaan teknologi informasi dan komunikasi, khususnya tindak pidana melalui media elektronik seperti telepon seluler (handphone).

Tindak pidana pengancaman melalui layanan pesan singkat dapat dijerat dengan ketentuan yang terdapat dalam UU ITE sebagai ketentuan khusus (lex specialis), sehingga mengenyampingkan ketentuan umum tentang tindak pidana pengancaman dalam KUHP (lex generalis).Hal ini sesuai dengan Pasal 63 ayat (2) KUHP bahwa Jika suatu perbuatan masuk dalam suatu aturan pidana yang umum dan diatur pula dalam aturan pidana khusus, maka yang khusus itulah yang diterapkan.

Tindak pidana pengancaman dalam UU ITE diatur dalam ketentuan sebagai berikut:

a. Pasal 27 ayat (4) menentukan bahwa "setiap orang dengan sengaja dan tanpa hak mendistribusikan dan/atau mentrasmisikan dan/atau membuat dapat diaksesnya Informasi Elektronik dan/atau Dokumen Elektronik yang memiliki muatan pemerasan dan/atau pengancaman."

b. Pasal 29 menentukan bahwa "Setiap orang dengan sengaja dan tanpa hak mengirimkan Informasi Elektronik dan/atau Dokumen elektronik yang berisi ancaman kekerasan atau menakut-nakuti yang ditujukan secara pribadi."

Dari ketentuan di atas,dapat diklasifikasi unsur-unsur yang dapat dibagi menjadi 2 bagian, yaitu:

1. Unsur Subjektif, adalah kesalahan pelaku yang dalam rumusan ketentuan undang-undang disebut "dengan sengaja" artinya bahwa kesalahan dalam tindak pidana pengancaman melalaui layanan pesan singkat harus dilakukan dengan unsur sengaja baik sebagai niat, sengaja karena kesadaran akan kemungkinan maupun sengaja akan keharusan;

2. Unsur objektif, adalah perbuatan melawan hukum. Unsur objektif dalam ketentuan Pasal 27 ayat (4) UU ITE sebagai berikut:

\section{a. Tanpa hak}

Melihat letak unsur sengaja mendahalui unsur perbuatan tanpa hak, maka tidak diragukan bahwa pelaku menghendaki untuk melakukan perbuatan mendistribusikan, mentransmisikan atau membuat dapat diaksesnya informasi elektronik. Kehendak ini, termasuk juga pengetahuan yang harus sudah terbentuk sebelum berbuat, karena demikian sifat kesengajaan orang hanya dapat menghendaki segala sesuatu yang sudah diketahuinya. Disamping itu, sengaja juga harus ditujukan pada unsur tanpa hak, artinya bahwa pelaku sebelum mendistribusikan, mentrasmisikan informasi elektronik atau dokumen elektronik tersebut, telah mengetahui atau menyadari bahwa ia tidak berhak melakukannya. 
b. Mendistribusikan

Adalah menyalurkan (membagi, mengirimkan) kepada beberapa orang atau tempat. Dalam konteks tindak pidana pengancaman menggunakan sarana teknologi informasi menurut UU ITE. Maka kiranya perbuatanmendistribusikan diartikan sebagai perbuatan dalam bentuk dan cara apapun yang sifatnya menyalurkan,membagikan, mengirimkan, memberikan, menyebarkan informasi elektronik kepada orang lain atau tempat lain dalam melakukan Informasi Elektronik dengan menggunakan tekhnologi informasi.

\section{c. Mentrasmisikan}

Dalam kamus Besar Bahasa Indonesia (2008:336), dirumuskan bahwa mentransmisikan adalah mengirimkan atau meneruskan pesan dari seseorang (benda) kepada orang lain (benda lain). Dari kalimat tersebut dengan menghubungkandengan objek yang ditransmisikan, maka perbuatan mentransmisikan dirumuskan pengertian, perbuatan dengan cara tertentu atau melalui perangkat tertentu mengirimkan atau meneruskan informasi dan/atau dokumen elektronik dengan memanfaatkan tekhnologi informasi kepada orang atau benda (perangkat elektronik) dalam usaha melakukan transaksi elektronik;

\section{d. Membuat dapat diakses}

Dihubungkan dengan objek tindak pidana berdasarkan Pasal 27 ayat

(4) UU ITE, perbuatan membuat dapat diaksesnya, adalah melakukan perbuatan dengan cara apapun melalui perangkat elektronik atau sekumpulan data elektronik dalam melakukan transaksi elektronik yang menyebabkan data elektronik tersebut, menjadi dapat diakses oleh orang lain atau benda lain;

\section{e. Mengirimkan}

Definisi dari kata mengirimkan, adalah menyampaikan, mengantarkan (dengan perantara) ke berbagai alamat tujuan dan sebagainya. Dalam hal ini, adalah menyampaikan informasi dan/atau dokumen elektronik.

\section{f. Objeknya, adalah informasi dan/atau dokumen elektronik yang memuat pemerasan dan/atau pengancaman}

Dengan menggunakan penafsiran gramatikal dan menerapkannya pada objek tindak pidana, maka dapat didefinisikan bahwa dokumen elektronik, adalah surat tertulis atau tercetak yang disimpan secara elektronik yang isinya dapat dipakai sebagai bukti berupa tulisan, suara, gambar, peta, rancangan, foto, Elektronic Data Interchage (EDI), surat elektronik (elektrik email), telegram, telecopy atau sejenisnya, huruf tanda, angka, kode akses, simbol atau perforasi yang telah diolah yang memiliki arti, atau dapat dipahami oleh orang yang mampu. Sementara dalam rumusan Pasal 29 mengenai objeknya, Informasi Elektronik dan/atau Dokumen Elektronik yang dimaksud, adalah berisi ancaman 
kekerasaan atau menakut-nakuti yang ditujukan secara pribadi.

Seseorang yang melakukan perbuatan yang dilarang UU ITE di atas, dapat dikenakan sanksi pidana sesuai dengan Pasal 45 ayat (3), yaitu bahwa setiap orang yang memenuhi unsur sebagaimana dimaksud dalam Pasal 29 dipidana dengan pidana penjara paling lama 12 (dua belas) tahun dan/atau denda paling banyak Rp. 2.000.000.000,00 (dua miliyar rupiah).

Layanan Pesan Singkat yang berisi ancaman tersebut, dapat ditafsirkan dengan menggunakan penafsiran hukum ekstensif yang diperluas, yaitu sebagai informasi elektronik yang berisi ancaman kekerasan, atau menakut-nakuti yang ditujukan secara pribadi sebagaimana dimaksud dalam Pasal 29 UU ITE. Dengan demikian, Layanan Pesan Singkat dapat dikategorikan sebagai informasi elektronik dan/atau data elektronik yang berisi ancaman kekerasan atau menakutnakuti yang ditunjukan secara pribadi dan dapat dijerat dengan Pasal 45 ayat (3) UU ITE.

Pasal 45 ayat (3), menentukan bahwa "Setiap orang memenuhi unsur sebagaimana dimaksud dalam Pasal 29 dipidana penjara paling lama 12 (dua belas) tahun dan/atau denda paling banyak Rp. 2.000.000.000,00 (dua miliyar rupiah)."

Dari ketentuan tersebut, dapat diperoleh unsur-unsur sebagai berikut:

a. Setiap orang, yang dimaksud dengan orang ialah manusia dan badan hukum;

b. Unsur dengan sengaja dan tanpa hak mengirimkan informasi dan/atau dokumen elektronik yang berisi ancaman kekerasan atau menakutnakuti yang ditujukan secara pribadi.

\section{PENUTUP}

Berdasarkan pembahasan di atas, maka dapat disimpulkan beberapa hal sebagai berikut:

a. Pembuktian tindak pidana pengancaman melalui layanan pesan singkat berdasarkan sekurang-kurangnya 2 alat bukti ditambah keyakinan hakim. Alat bukti yang sah dapat berupa keterangan saksi, keterangan ahli, surat, petunjuk, dan keterangan terdakwa serta informasi/dokumen elektronik sebagai perluasan alat bukti dalam ketentuan UU ITE sedangkan cetakannya merupakan perluasan alat bukti surat dalam KUHP; dan

b. Tindak pidana pengancaman melalui layanan pesan singkat harus memenuhi unsur-unsur,yaitu dengan sengaja, tanpa hak, mengirimkan, objeknya berupa Informasi Elektronik dan/atau dokumen elektronik yang berisi ancaman kekerasan atau menakut-nakuti yang ditujukan secara pribadi.

\section{DAFTAR PUSTAKA}

Abdul Wahid dan M. Labib, 2005, Kejahatan Mayantara (cybercrime), Bandung: Refika Aditama. 
Chazawi Adami dan Ferdian Ardi, 2015, Tindak Pidana Informasi dan Transaksi Elektronik, Malang: Media Nusa Creative.

Dikdik M Arief Mansur dan Elisatris Gultom, 2005, Cyber Law Aspek Hukum Tekhnologi Informasi, Bandung : Repika Aditama.

Djoko Sarwoko, 2009, Pembuktian Perkara Pidana setelah Berlakunya UndangUndang Nomor 11 Tahun 2008. Jakarta: Mahkamah Agung.

Djanggih, H., Thalib, H., Baharudin, H., \& Qamar, N. 2017. Urgency Legal Aspects of Growth Information Technology In Indonesian. Urgency Legal Aspects of Growth Information Technology In Indonesia, 84.

Hambali Thalib, Farid Yusuf, 2016. Cyber Crime Tantangan dan Penanggulangannya Studi Kasus pada Polrestabes Makassar

Josua Sitompul, 2012, Cyberspace, cybercrimes, cyberlaw, Tinjauan aspek Hukum Pidana. Jakarta: PT. tatanusa.

Shinta Dewi. 2009, Cyberlaw (Perlindungan Privasi atas Informasi Pribadi dalam E-Commerce Menurut Hukum Internasional), Bandung: Widya Padjajaran. 